\title{
The Needs Analysis of Increasing Teachers' Pedagogical Competences of Inclusive Education
}

\author{
Sukinah, Cece Rakhmat, Endang Rochyadi, Sunardi \\ Special Education Department, Doctoral Program, UPI Bandung Indonesia \\ Bandung, Indonesia \\ suk_uny@yahoo.com,cece.rakhmat@upi.edu,endangrochyadi@upi.edu, nardilembang@upi.edu
}

\begin{abstract}
Teachers in regular schools have general competencies and knowledge of teaching, but they do not master the specific competencies to teach students with special needs. In order to work in a classroom that implements inclusive education, teachers need to know the specific characteristics of the students' conditions, teaching strategies and competence development of learners to create a positive environment for learning. The purpose of this study was to identify problems faced by teachers, problem-solving, challenges and expectations in the implementation of learning in the inclusive class setting. Survey method with an open questionnaire instrument was used to collect the data. There were 83 primary school teachers of inclusive education in Yogyakarta participated in this study. Purposive random sampling was used to determine the participant. The study asked some common questions like age, gender, level of education and experience of working in schools with an inclusive classroom setting. Other questions were about teachers' expectations, barriers in teaching in inclusive settings, the capacity of inclusive education implementation, training topics, things and services needed by teachers and schools. The result of this study indicates that $90 \%$ of 83 teachers experienced problems in managing an inclusive classroom setting. Qualitatively, teachers need to increase their pedagogical competencies because 83 respondents experienced problems in understanding learners especially students with special needs, making a lesson plan, learning management, evaluation or assessment which suitable with the inclusive setting.
\end{abstract}

Keywords-needs analysis; pedagogical competence; inclusive education.

\section{INTRODUCTION}

Inclusive education is education that allows all students to learn together with others regardless of the conditions of difficulties or differences in them. Inclusive education provides a suitable place and equal learning rights including for special needs students who study together with other students in regular schools in their neighborhood. Inclusive education has been spread in Indonesia by government accommodation in regulation through Ministerial Regulation No. 70 of 2009 that "the system of education provides opportunities for all students who have abnormalities and potential intelligence and/or special talent to attend education or learning together with other students in general". Inclusive education is essential for every child who has a variety of different needs in learning. In the perspective of inclusive education, children are understood as unique individuals who have various kinds of needs so that the implementation of education must refer to the adaptation and accommodation systems according to the needs of each child. Data from the Central Statistics Agency (BPS) estimated that the number of children with special needs in Indonesia is 1.6 million children. The Ministry of Education and Culture has provided some efforts, one of them is access to learn for those students. From 1.6 million children with special needs, $10 \%$ or 229 thousand got inclusive education services while 115 thousand went to special school and the rest got other services.

Teachers are the most important variable of the success of inclusive education programs [1], [2]. Teachers have a functional strategy in the process of education services; it means they have an important role to improve the quality of the education process. The practice of inclusive education in schools needs teachers who are fitted to accommodate all students in any condition including students with special needs. Therefore, the implementation of inclusive education requires teachers who have adequate competence to accommodate the needs of inclusive students. Teacher's quality is an important factor in student learning [3]. Teacher as the most important factor in the inclusive education process, she or he has an obligation to create an environment that is appropriate and can stimulate students to learn. Teachers must have certain professional and personal competencies in providing services that are suitable to the students' needs. Personal competence can be observed through attitudes and motivation in teaching students with special needs in school settings. Professional competence can be seen through the ability to recognize the characteristics of students with special needs and their abilities to learn. Bradshaw and Mundia [4] said that there are several variables in influencing the inclusion process, they are (i) teaching efficiency, work experiences of the teachers, (ii) beliefs about students and their education, (iii)the educational environment in which they place themselves and (iv) the availability of support.

An inclusive teacher who has pedagogical competence is a teacher who is able to adjust to any situations of students such as intelligence, cognitive, affective, psychomotor and 
social economic conditions of students in an inclusive class. Accommodating all children's learning needs can be done by modifying the curriculum, teaching methods, infrastructure facilities, and the evaluation systems. Competence comes from English with the basic word compete; it means to compete, contend, contest, then it is used as a noun becomes competence or competency which means ability, capability, or authority. Then, there are several terminological definitions of competence. For example, competence is a set of knowledge, skills, and behaviors that must be internalized, and controlled by a person in carrying out professional duties [5]. Teachers are defined as professional educators with the main task of educating, teaching, guiding, directing, training, assessing, and evaluating students in early childhood education through formal education, primary education, and secondary education [5]. Teachers' competence is a set of knowledge, abilities, and beliefs possessed by a teacher and displayed for teaching situations. In other words, teacher competence is a set of knowledge, skills, and behaviors that must be possessed, lived, and mastered by the teacher in carrying out professional tasks. One of them is pedagogical competence, which the ability to manage and understand the students to actualize the various potentials they have. For example, being able to decide why, when, where, and how a material supports the purpose of teaching and how to choose the types of material that are suitable for the learning's needs.

An effective teacher is necessary to have good theoretical knowledge about learning, mastery of subject matter to be taught, teaching skills, and attitudes that encourage human learning and relationships. Teachers are one of the keys in realizing the new and qualified education policies implementation (including inclusive education policies) [6]. Teachers should have a positive attitude towards inclusive education so they can be more sensitive and flexible when teaching children with special needs [7]. Teachers are key players in determining the quality of the implementation of new education policies (including new inclusion policies) [6]. The perceptions and attitudes of teachers often determined by the success integration, rather than their professional knowledge and formal preparation. Competence as a whole of different knowledge, skills, understanding, values, attitudes and desires leads to effective human actions and manifested in the world in certain domains [8]. Pedagogical competence needs to be understood by the teacher as a permanent sustainable process. It is necessary to understand the pedagogical competence of the teacher as an ongoing process that is permanently submitted as assessment through interaction with colleagues, students, parents and others [9]. In the context of an inclusive process, various students and challenges must be faced by schools and classrooms

This study aims to identify the problems faced by teachers in aspects of pedagogical competency which include understanding the diversity and characteristics of students, classroom management, curriculum development, modification of learning programs, problem solving strategies that have been done by the teachers in learning so far, challenges and expectations in implementation of learning in inclusive classroom settings.

\section{METHOD}

The study was carried out in the primary inclusive schools. This study used survey research with open questionnaire instruments to collect the data. The subjects of this study were 83 primary school teachers of inclusive education in Yogyakarta. The purposive random sampling was used to determine the subjects. The instruments used in data collection included several aspects of general questions about age, gender, level of education and experience of working in inclusive classroom settings school. Other questions were about teacher expectations, barriers during learning in an inclusive setting, the capacity of inclusive education implementation, training topics, things and services needed by teachers and schools.

\section{RESULT AND DISCUSSION}

This study provides several aspects of general questions about age, gender, level of education and work experience in school with inclusive classroom settings. The other questions were about teacher expectations, barriers during learning in an inclusive setting, the ability to implement inclusive education, training topics, things and services needed by teachers and schools. The results obtained the following data on Table I:

TABLE I. TEACHING EXPERIENCE

\begin{tabular}{|l|l|l|}
\hline \multicolumn{3}{|c|}{ Sum of respondents } \\
\hline \multicolumn{1}{|c|}{ From teaching experience } & Total & Percentage \\
\hline $\begin{array}{l}\text { Teacher has teaching experience of special } \\
\text { needs students }\end{array}$ & 0 & 0 \\
\hline $\begin{array}{l}\text { Teacher has teaching experience of regular } \\
\text { students }\end{array}$ & 33 & $40 \%$ \\
\hline $\begin{array}{l}\text { Teacher has teaching experience of both } \\
\text { special needs students and regular students }\end{array}$ & 50 & $60 \%$ \\
\hline Total & 83 & $100 \%$ \\
\hline
\end{tabular}

From 83 teachers, 50 teachers or $60 \%$ of the subjects experienced in teaching regular students and special needs students. 33 teachers of $40 \%$ experienced in teaching regular students. As presented in Table I it was found that that schools have provided learning opportunities for students with special needs to study along with other students. The data obtained in Table II, showed teachers' educational background shows. As presented, 93\% of 83 teachers are undergraduate level, and none is a doctorate. This tabe showed, the average level of teachers' education is in college. Teachers are important actors in the process of renewal in educational services in schools [10] The expectation is the more teacher understands and able to carry out inclusive education in his/her school, the more the teacher can share his/her knowledge to the community. While the results of research from 83 teachers based on age are shown in Table III. 
TABLE II. TEACHERS' EdUCATIONAL BACKGROUND

\begin{tabular}{|l|l|l|}
\hline \multicolumn{3}{|c|}{ Sum of respondents } \\
\hline \multicolumn{1}{|c|}{ Level of education } & Percentage \\
\hline Diploma & 2 & 2 \\
\hline Undergraduate & 77 & 93 \\
\hline Postgraduate/Master & 4 & 5 \\
\hline Doctoral & 0 & 0 \\
\hline Total & 83 & 100 \\
\hline
\end{tabular}

TABLE III. TEACHERS' AGE

\begin{tabular}{|l|l|l|}
\hline \multicolumn{2}{|c|}{ Sum of respondents } \\
\hline \multicolumn{1}{|c|}{ Age } & \multicolumn{1}{c|}{ Total } & \multicolumn{1}{c|}{ Percentage } \\
\hline $15-25$ & 10 & $12 \%$ \\
\hline $25-35$ & 18 & $22 \%$ \\
\hline 35 above & 55 & $66 \%$ \\
\hline Total & 83 & $100 \%$ \\
\hline
\end{tabular}

TABLE IV. LENGTH TEACHING EXPERIENCES

\begin{tabular}{|l|l|l|}
\hline \multicolumn{3}{|c|}{ Sum of respondents } \\
\hline Length of the teaching experience & Total & Percentage \\
\hline 1 year & 3 & $4 \%$ \\
\hline 2-3 years & 10 & $12 \%$ \\
\hline 4-5 years & 8 & $10 \%$ \\
\hline 6-10 years & 11 & $13 \%$ \\
\hline More than 10 years & 51 & $61 \%$ \\
\hline Total & 83 & $100 \%$ \\
\hline
\end{tabular}

Based on Table III, it is showed that teachers who are teaching are $66 \%$ of the age of above 35 years old and $12 \%$ of the age of $15-25$. Most $61 \%$ of teachers have more than 10 years of teaching experiences and at least $4 \%$ of teachers have 1-year experience. According to International Helen Keller Team study in the Special Capital Region of Jakarta, showed socialization of inclusive program have been carried out to help teachers gain knowledge. In the context of the socialization program bureaucracy, it is more intended to equate perception of the implementation program rather than increasing competence. Therefore, it can be concluded that the teacher has less competence in teaching students with special needs in inclusive schools.

TABLE V. TEACHERS' GENDER

\begin{tabular}{|l|l|l|}
\hline \multicolumn{3}{|c|}{ Sum of respondents } \\
\hline \multicolumn{1}{|c|}{ Total } & \multicolumn{1}{c|}{ Percentage } \\
\hline Men & 24 & 29 \\
\hline Women & 59 & 71 \\
\hline Total & 83 & 100 \\
\hline
\end{tabular}

Table V shows that from 83 teachers, $71 \%$ are women and $29 \%$ are men. The data also showed that the average teacher has been teaching before the inclusive education is conducted in Indonesia; they have not learnt and got knowledge about inclusive education and special needs students yet in their college. The policy of inclusive education provides opportunities for students with special needs to study together with their peers without discrimination. Therefore, it needs support from various parties including teacher as the main factor in teaching learning process.

The quality of the implementation of inclusive education influenced by the teachers 'role. In accordance with Minister of Education and Culture Regulation No. 16 of 2007 teacher should has four competencies needed (pedagogical, professional, social, and personality), these aspects are expected to create a quality level of an inclusive education system in schools as well [11]. According to the constituent as explained in no 28(3), about national education standard, stated that what is meant by pedagogic competence is the ability to manage students' learning including the understanding of students, designing and implementing learning, evaluating learning outcomes, and developing students to develop their potential. This research focused on the aspects of the teacher's pedagogic competence in implementing inclusive education. The results of the study showed the pedagogical competence of each aspect.

TABLE VI. ASPECTS OF TEACHER PEDAgOgICAL COMPETENCY IN INCLUSIVE CLASSROOM SETTING (MINISTER OF EDUCATION AND CULTURE REGULATION NO. 16 OF 2007)

\begin{tabular}{|c|c|}
\hline Aspects & Description \\
\hline $\begin{array}{l}\text { Mastering } \\
\text { characteristics of } \\
\text { students from the } \\
\text { physical, moral, } \\
\text { spiritual, social, } \\
\text { cultural, emotional } \\
\text { and intellectual } \\
\text { aspects. }\end{array}$ & $\begin{array}{l}\text { In connection with the way the teacher } \\
\text { understands the characteristics of students } \\
\text { related to the physical, intellectual, social } \\
\text { emotional, moral, spiritual, and socio- } \\
\text { cultural backgrounds, they have not } \\
\text { conducted an initial assessment on children. } \\
\text { Not all teachers involve interviews with } \\
\text { parents that can describe the intellectual and } \\
\text { emotional state of children, so that it can be } \\
\text { known how to handle and develop the right } \\
\text { curriculum for children in learning. Based on } \\
\text { the results of an open questionnaire, not all } \\
\text { teachers have identified the potential and } \\
\text { learning difficulties of students per subject. } \\
\text { This turned out to be directly proportional to } \\
\text { the high competency of the teacher in the } \\
\text { experience of dealing with children with } \\
\text { special needs. In general, the more often } \\
\text { teachers meet with students in class, the } \\
\text { more the teacher feels burdened in designing } \\
\text { the implementation of learning. }\end{array}$ \\
\hline $\begin{array}{lr}\text { Mastering learning } \\
\text { theory } & \text { and } \\
\text { educational learning } \\
\text { principles. }\end{array}$ & $\begin{array}{l}\text { Teachers understand various learning } \\
\text { theories and learning principles that educate } \\
\text { in relation to the subjects taught in general } \\
\text { but specifically not mastered. Teachers in } \\
\text { applying various approaches, strategies, } \\
\text { methods, and learning techniques that } \\
\text { educate creatively in the subjects being } \\
\text { taught have not been specifically for students } \\
\text { with special needs. The results show that } \\
85 \% \text { of the teachers say that they have not } \\
\text { yet received an introduction to learning } \\
\text { theory and learning principles for children } \\
\text { with special needs }\end{array}$ \\
\hline
\end{tabular}




\begin{tabular}{|c|c|}
\hline Aspects & Description \\
\hline $\begin{array}{l}\text { Develop a } \\
\text { curriculum related to } \\
\text { the subject being } \\
\text { taught. }\end{array}$ & $\begin{array}{l}90 \% \text { teachers do not understand the } \\
\text { principles of curriculum development, } \\
\text { Determine the learning objectives that are } \\
\text { taught, Determine the learning experience } \\
\text { that is appropriate to achieve the learning } \\
\text { objectives that are taught, Choose the } \\
\text { learning material that is taught related to the } \\
\text { learning experience and learning objectives. } \\
\text { Organize learning material correctly } \\
\text { according to the chosen approach and } \\
\text { characteristics of students, Develop } \\
\text { indicators and assessment instruments. The } \\
\text { teacher said that they were still experiencing } \\
\text { confusion in preparing the curriculum in } \\
\text { accordance with the conditions of various } \\
\text { students. }\end{array}$ \\
\hline $\begin{array}{l}\text { Organizing } \\
\text { Educating Learning }\end{array}$ & $\begin{array}{l}80 \% \text { teachers do not understand the } \\
\text { principles of learning design that educate } \\
\text { students with special needs, Develop } \\
\text { components of learning design, Compile a } \\
\text { complete learning design, both for activities } \\
\text { in the classroom, laboratory, and field. Carry } \\
\text { out learning that educates in the classroom, } \\
\text { in the laboratory, and in the field by } \\
\text { observing the required safety standards. } \\
\text { Using learning media and learning resources } \\
\text { that are relevant to the characteristics of } \\
\text { students and subjects that are taught to } \\
\text { achieve the learning objectives as a whole. } \\
\text { Take transactional decisions in the learning } \\
\text { that is taught in accordance with the } \\
\text { developing situation for students with special } \\
\text { needs. }\end{array}$ \\
\hline $\begin{array}{l}\text { Students' potential } \\
\text { development }\end{array}$ & $\begin{array}{l}70 \% \text { of the teachers stated that they have not } \\
\text { been able to analyse the learning potential of } \\
\text { each student and identify the development of } \\
\text { the potential of students through learning } \\
\text { programs that support students to actualize } \\
\text { their academic potential, personality, and } \\
\text { creativity until there is clear evidence that } \\
\text { students actualize their potential including } \\
\text { students with special needs. So far, not all } \\
\text { teachers have received training or assistance } \\
\text { in developing potential, especially for } \\
\text { children with special needs. Teachers have } \\
\text { not been able to provide learning } \\
\text { opportunities to students in accordance with } \\
\text { their respective learning methods, especially } \\
\text { for students with special needs. }\end{array}$ \\
\hline $\begin{array}{l}\text { Communication } \\
\text { with students. }\end{array}$ & $\begin{array}{l}\text { Teachers are able to communicate } \\
\text { effectively, empathetically and politely with } \\
\text { students and be enthusiastic and positive. } \\
\text { Teachers are able to provide a complete and } \\
\text { relevant response to the comments or } \\
\text { questions of students in general, but if there } \\
\text { are students with special needs in the } \\
\text { classroom, then they will experience } \\
\text { difficulties especially in building } \\
\text { communication using special methods. For } \\
\text { example: sign language, the teacher has not } \\
\text { received training or mentoring in AAC } \\
\text { (Alternative Augmentative Communication) }\end{array}$ \\
\hline $\begin{array}{l}\text { Assessment and } \\
\text { Evaluation. }\end{array}$ & $\begin{array}{l}\text { Teachers have not been able to hold an } \\
\text { assessment of the process and learning } \\
\text { outcomes continuously for students with } \\
\text { special needs. Teachers evaluate the } \\
\text { effectiveness of learning processes and } \\
\text { outcomes and use information from the } \\
\text { assessment and evaluation results to design } \\
\text { remedial and enrichment programs. Teachers }\end{array}$ \\
\hline
\end{tabular}

\begin{tabular}{|l|l|}
\hline Aspects & \multicolumn{1}{c|}{ Description } \\
\hline & $\begin{array}{l}\text { are able to use the results of assessment } \\
\text { analysis in the learning process in general. } \\
\text { Teachers have been confused in determining } \\
\text { class upgrades and graduation for students } \\
\text { with special needs. }\end{array}$ \\
\hline
\end{tabular}

The results in this study indicate $90 \%$ of 83 teachers have problems in managing inclusive class settings. Qualitatively the teacher needs an increase in pedagogical competence because 83 respondents were experienced problems in the understanding of learners, especially children with special needs, making lesson plans, managing learning, evaluating or assessing according to inclusive settings. While qualitatively the result showed that the teacher faced problem in providing services for students with special needs, teachers' needs, and teachers' suggestions and expectations are summarized in the following table:

TABLE VII. ANALYSIS OF SERVICE PROBLEMS FOR CHILDREN WITH SPECIAL NEEDS, TEACHERS' NEEDS AND TEACHERS' EXPECTATIONS

\begin{tabular}{|c|c|c|}
\hline $\begin{array}{l}\text { Problems encountered in } \\
\text { the service of children } \\
\text { with special needs }\end{array}$ & Teacher needs & $\begin{array}{c}\text { Teacher's } \\
\text { suggestions } \\
\text { and } \\
\text { expectations }\end{array}$ \\
\hline $\begin{array}{l}\text { difficult in narrating } \\
\text { images, braille letter } \\
\text { teaching materials are not } \\
\text { sufficient, teachers' } \\
\text { knowledge and skills in } \\
\text { handling children with } \\
\text { special needs are still } \\
\text { lacking, inadequate } \\
\text { directions, blind students } \\
\text { sometimes have high } \\
\text { emotional characteristics }\end{array}$ & $\begin{array}{l}\text { Skills training to handle } \\
\text { children with special } \\
\text { needs, special assistance } \\
\text { by experts, aids } \\
\text { (recorders, laptops } \\
\text { specifically for blind } \\
\text { people), learning } \\
\text { resources / braille books, } \\
\text { special room / resource } \\
\text { room for students with } \\
\text { special needs }\end{array}$ & $\begin{array}{l}\text { There is follow- } \\
\text { up training } \\
\text { (especially in } \\
\text { dealing with } \\
\text { children with } \\
\text { special needs), } \\
\text { assistance in } \\
\text { facilities and } \\
\text { infrastructure, } \\
\text { assistance from } \\
\text { a companion }\end{array}$ \\
\hline $\begin{array}{l}\text { teacher competencies } \\
\text { related to curriculum and } \\
\text { learning of children with } \\
\text { special needs, school } \\
\text { facilities and infrastructure } \\
\text { such as sources of } \\
\text { learning, parental } \\
\text { participation that are less } \\
\text { cooperative and } \\
\text { informative at school, } \\
\text { communication with } \\
\text { inclusion students }\end{array}$ & $\begin{array}{l}\text { practical learning } \\
\text { workshops for school } \\
\text { teachers providing } \\
\text { inclusive education, } \\
\text { workshops on treatment } \\
\text { of children with special } \\
\text { needs for teachers in } \\
\text { schools providing } \\
\text { inclusive education, } \\
\text { teacher shadow for } \\
\text { students with special } \\
\text { needs in school, facilities } \\
\text { and infrastructure related } \\
\text { to learning activities of } \\
\text { children with special } \\
\text { needs such as tables and } \\
\text { chairs for quadriplegic }\end{array}$ & $\begin{array}{l}\text { need special } \\
\text { assistant } \\
\text { teachers who } \\
\text { help subject } \\
\text { teachers, } \\
\text { facilities and } \\
\text { infrastructure } \\
\text { such as books } \\
\text { and resource } \\
\text { rooms, parent } \\
\text { and community } \\
\text { collaboration, } \\
\text { government } \\
\text { participation in } \\
\text { socialization of } \\
\text { parents and the } \\
\text { community }\end{array}$ \\
\hline $\begin{array}{l}\text { Delivery of subject matter, } \\
\text { it takes a longer time to } \\
\text { understand a subject } \\
\text { matter, the demands of the } \\
\text { Minimum Completeness } \\
\text { Criteria (KKM) that have } \\
\text { been determined }\end{array}$ & $\begin{array}{l}\text { Need supporting } \\
\text { facilities and } \\
\text { infrastructure that are } \\
\text { needed by children with } \\
\text { special needs (for their } \\
\text { deficiencies), Training } \\
\text { for subject teachers to } \\
\text { provide good lessons for } \\
\text { children with special } \\
\text { needs, special assistant } \\
\text { teachers }\end{array}$ & $\begin{array}{l}\text { Need special } \\
\text { assistant } \\
\text { teachers in } \\
\text { accordance with } \\
\text { the specificity } \\
\text { of students with } \\
\text { special needs in } \\
\text { schools because } \\
\text { until now there } \\
\text { has not been a } \\
\text { teacher }\end{array}$ \\
\hline
\end{tabular}




\begin{tabular}{|c|c|c|}
\hline $\begin{array}{l}\text { Problems encountered in } \\
\text { the service of children } \\
\text { with special needs }\end{array}$ & Teacher needs & $\begin{array}{c}\text { Teacher's } \\
\text { suggestions } \\
\text { and } \\
\text { expectations } \\
\end{array}$ \\
\hline & & $\begin{array}{l}\text { specifically } \\
\text { accompanying } \\
\text { children with } \\
\text { special needs, } \\
\text { there is a need } \\
\text { for training of } \\
\text { subject teachers } \\
\text { in schools that } \\
\text { provide } \\
\text { inclusive } \\
\text { education }\end{array}$ \\
\hline $\begin{array}{l}\text { mentoring, lack of } \\
\text { understanding of children } \\
\text { with special needs }\end{array}$ & Patience / Heart & $\begin{array}{l}\text { Continuously } \\
\text { developed } \\
\text { services and } \\
\text { learning media }\end{array}$ \\
\hline $\begin{array}{l}\text { children find it difficult to } \\
\text { accept lesson material, } \\
\text { children are difficult to } \\
\text { control in class and } \\
\text { sometimes do not want to } \\
\text { do assignments in class, } \\
\text { there is still access to } \\
\text { school buildings that are } \\
\text { not yet accessible, making } \\
\text { it difficult for disabled } \\
\text { children }\end{array}$ & $\begin{array}{l}\text { teachers need to compile } \\
\text { material that is } \\
\text { appropriate for the } \\
\text { abilities of children with } \\
\text { special needs, teachers } \\
\text { need to understand the } \\
\text { character of children } \\
\text { with special needs, } \\
\text { provide facilities for } \\
\text { disabled children }\end{array}$ & $\begin{array}{lr}\begin{array}{l}\text { manuals } \\
\text { children } \\
\text { special nor }\end{array} \\
\text { nith } \\
\text { are needs } \\
\text { according to the } \\
\text { type of children } \\
\text { with special } \\
\text { needs and } \\
\text { levels, it takes } \\
\text { patiencer to } \\
\text { determine the } \\
\text { right method for } \\
\text { children with } \\
\text { special needs, } \\
\text { special shoes } \\
\text { and special } \\
\text { roads are } \\
\text { needed so there } \\
\text { is no need to go } \\
\text { up and down } \\
\text { the stairs }\end{array}$ \\
\hline $\begin{array}{l}\text { Lack of understanding of } \\
\text { teachers related to slow } \\
\text { learners, lack of special } \\
\text { assistant teachers }\end{array}$ & $\begin{array}{l}\text { Learning } \quad \text { CD, } \\
\text { assistant teachers }\end{array}$ & \\
\hline $\begin{array}{l}\text { difficulty in teaching } \\
\text { students, lack of } \\
\text { explanation } \\
\text { socialization or } \\
\text { handling children with } \\
\text { special needs, lack of } \\
\text { agreement (commitment) } \\
\text { to deal with children with } \\
\text { special needs }\end{array}$ & $\begin{array}{l}\text { Supporting modules, } \\
\text { training, socialization }\end{array}$ & $\begin{array}{l}\text { there is a group } \\
\text { to share with } \\
\text { each other, it is } \\
\text { necessary to } \\
\text { share the } \\
\text { training } \\
\text { workshop } \\
\text { because there } \\
\text { are many } \\
\text { problems that } \\
\text { arise, there } \\
\text { needs to be a } \\
\text { socialization to } \\
\text { the school that } \\
\text { organizes the } \\
\text { inclusion in } \\
\text { order to get a } \\
\text { commitment for } \\
\text { the teacher }\end{array}$ \\
\hline
\end{tabular}

\begin{tabular}{|c|c|c|}
\hline $\begin{array}{l}\text { Problems encountered in } \\
\text { the service of children } \\
\text { with special needs }\end{array}$ & Teacher needs & $\begin{array}{c}\text { Teacher's } \\
\text { suggestions } \\
\text { and } \\
\text { expectations } \\
\end{array}$ \\
\hline $\begin{array}{l}\text { lack of support from other } \\
\text { parties, there is no } \\
\text { collaboration between } \\
\text { teachers of children with } \\
\text { special needs and regular } \\
\text { teachers }\end{array}$ & $\begin{array}{l}\text { education for regular } \\
\text { teachers in preparing } \\
\text { special } \\
\text { programs for } \\
\text { whorning } \\
\text { students } \\
\text { services, education for } \\
\text { regular teachers in } \\
\text { composing a special } \\
\text { program for children } \\
\text { with special needs, } \\
\text { education for regular } \\
\text { teachers in the } \\
\text { preparation of special } \\
\text { learning curriculums for } \\
\text { students who need } \\
\text { special services }\end{array}$ & $\begin{array}{l}\text { education } \\
\text { training is held } \\
\text { for regular } \\
\text { teachers } \\
\text { regarding } \\
\text { inclusive } \\
\text { education, so } \\
\text { that the } \\
\text { government will } \\
\text { pay more } \\
\text { attention by } \\
\text { allocating funds } \\
\text { to children with } \\
\text { special needs to } \\
\text { build } \\
\text { infrastructure } \\
\text { for them }\end{array}$ \\
\hline
\end{tabular}

Improving teachers' understanding and competence is very important because teachers are the major factor in the implementation of education. The government has a responsibility for professional development/improvement of teacher competencies, although sometimes the responsibility system is partly left to school organizations because schools also have a role to make changes in their schools, especially principals [10]. Pedagogical competence helps teachers to recognize the potential, conditions, rights and needs of the students; therefore they are able to design an effective and an appropriate learning as well. Teachers' ability to master science and technology is also included in professional competence, thus provide meaningful learning experiences for students. Teachers' ability to communicate and interact with students, parents, and stakeholders are described in the teacher's social competence, it is expected the teachers can overcome social problems as well. In addition, the role of the teacher as a good example for students and creating a motivated learning atmosphere is within the teacher's personality competence. In line with Lopes, teachers feel a lot of burdens when dealing with students with special educational needs who need more time and attention than other friends and do not show results that match expectations [12].

\section{CONCLUSION}

This study showed that 50 teachers or $60 \%$ of teachers experienced in teaching regular students and special needs meanwhile 33 teachers or $40 \%$ of teachers only experienced in teaching regular students. Most of the teacher, $93 \%$ out of 83 teachers are from undergraduate/bachelor degree level and none is a doctorate. In general, teachers' level of education is in college. Teachers have an important role in the process of renewal in educational services in schools. Qualitatively, the teacher needs to increase their pedagogical competence because most of the respondents experienced problems in the understanding students, especially children with special needs, making lesson plans, managing learning, 
evaluating or assessments that suitable with the inclusive setting doesn't have clear standards yet. Teacher's pedagogical competence as used in this study can determine how far the inclusive teachers have competencies that are fundamental for the teaching and learning process, especially for children with special needs.

\section{SUGGESTION}

Teachers should have responsibility to not only transferring the knowledge, but also providing opportunity all students without discrimination. Therefore, it is necessary for teachers to gain more knowledge, skills and attitudes. Other researchers could conduct and develop similar research in competency aspects in addition to pedagogical competency, so that they will find a framework for developing 4 competencies according to the Ministry of National Education.

\section{REFERENCES}

[1] N. Bhatnagar and A. Das, "Attitudes of secondary school teachers towards inclusive education in New Delhi, India," Journal of Research in Special Educational Needs, vol. 14, no. 4, pp. 255-263, Jul. 2013.

[2] A. K. Das, M. Gichuru, and A. Singh, "Implementing inclusive education in Delhi, India: regular school teachers' preferences for professional development delivery modes," Professional Development in Education, vol. 39, no. 5, pp. 698-711, Nov. 2013.
[3] L. P. Blanton, P. T. Sindelar, and V. I. Correa, "Models and Measures of Beginning Teacher Quality," The Journal of Special Education, vol. 40, no. 2, pp. 115-127, Aug. 2006

[4] L. Bradshaw, and L. Mundia, "Attitudes and concerns about inclusive education: Bruneian inservice and preservice teachers," International Journal of Special Education, vol. 21, no. 1, pp. 35-41, 2006.

[5] R. I. Undang-Undang, Nomor 14 tahun 2005 tentang Guru dan Dosen, Bandung: Penerbit Fokusmedia, 2006

[6] B. French, "Book Reviews : Change Forces: Probing the Depths of Education Reform Michael Fullan (Falmer Press, 1993), £12.95 paperback ISBN 185000826 4," Educational Management \& Administration, vol. 22, no. 3, pp. 214-216, Jul. 1994.

[7] C. M. Fairbanks, G. G. Duffy, B. S. Faircloth, Ye He, B. Levin, J Rohr, and C. Stein, "Beyond Knowledge: Exploring Why Some Teachers Are More Thoughtfully Adaptive Than Others," Journal of Teacher Education, vol. 61, no. 1-2, pp. 161-171, Oct. 2009.

[8] R. U. T. H. C. Deakin, Pedagogy for citizenship. Getting involved Global citizenship development and sources of moral values, 2008.

[9] M. Ljubetić, and V. V. Kostović, "Pedagogical (in) competence of teachers," Educational science, vol. 10, no. 1, pp. 209-230, 2008.

[10] S. Carrington and R. Robinson, "A case study of inclusive schoo development: a journey of learning," International Journal of Inclusive Education, vol. 8, no. 2, pp. 141-153, Apr. 2004.

[11] R.I. Depdiknas, Peraturan Menteri Pendidikan Nasional Nomor 16 tahun 2007 tentang Standar Kompetensi Guru, Jakarta: Biro Hukum dan Organisasi Sekretariat Jendral Departemen Pendidikan Nasional, 2007.

[12] J. A. Lopes, I. Monteiro, V. Sil, R. B. Rutherford, and M. M. Quinn, Teachers' perceptions about teaching problem students in regular classrooms, Education and treatment of children, 2004 